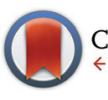

CrossMark \& click for updates

Cite this: Dalton Trans., 2016, 45 13525

Received 5th June 2016, Accepted 26th July 2016

DOI: $10.1039 / c 6 d t 02242 a$

www.rsc.org/dalton

\title{
Palladium nanoparticles supported on a nickel pyrazolate metal organic framework as a catalyst for Suzuki and carbonylative Suzuki couplings $\uparrow$
}

\author{
A. W. Augustyniak, ${ }^{a}$ W. Zawartka, ${ }^{a}$ J. A. R. Navarro*b and A. M. Trzeciak*a \\ Methanolic reduction of $\left[\mathrm{PdCl}_{2}\left(\mathrm{CH}_{3} \mathrm{CN}\right)_{2}\right]$ on a $\left[\mathrm{Ni}(2,5 \text {-di(1 } \mathrm{H} \text {-pyrazol-4-yl)benzenesulfonate })_{2}\right]$ metal \\ organic framework gives rise to $\mathrm{Pd}^{2+} / \mathrm{Pd}^{0}$ nanocomposites with Suzuki and carbonylative Suzuki hetero- \\ geneous catalytic activities.
}

One of the major challenges in modern catalysis is the efficient separation of a metal catalyst from organic products. ${ }^{1-7}$ This is particularly important in palladium catalysed cross-coupling reactions that lead to products which can be utilized in the pharmaceutical industry. For example, the Suzuki-Miyaura reaction presents an attractive pathway to substituted biaryls, precursors of anti-inflammatory drugs. ${ }^{8-12}$ The carbonylative Suzuki-Miyaura coupling offers easy access to diarylated ketones used in UV-screens, dyes, agrochemicals and pharmaceuticals. ${ }^{13-15}$

Application of heterogeneous catalysts to these reactions enables improvement of the separation step and minimizes the palladium content in the reaction products. In this regard, metal organic frameworks, MOFs, have attracted an increasing attention as potential supports for palladium. ${ }^{16-22}$ Advantageously, MOFs possess large surface areas with well-defined pores of shapes that can be modulated. These highly porous materials can be easily modified by several functional groups facilitating the bonding of a variety of metal ions and metal nanoparticles (NPs). ${ }^{16-22}$

One of the first reports dealing with the application of the MOF in the Suzuki-Miyaura reaction was the palladium(II) based system $\left[\operatorname{Pd}(2-\text { pymo })_{2}\right]_{n}$ (2-pymo $=2$-hydroxypyrimidinolate $)^{23,24}$ which remained unaltered under the reaction conditions, at $150{ }^{\circ} \mathrm{C}$, as proven by X-ray powder diffraction. ${ }^{24}$ Other MOFs, mainly carboxylate systems of the MIL family, were used as supports for palladium catalysts of the Suzuki-Miyaura coupling. ${ }^{25-36}$ Thus, Pd NPs immobilized on MIL-101(Cr) formed efficient heterogeneous catalysts of the

\footnotetext{
${ }^{a}$ Faculty of Chemistry, University of Wroctaw, 14 F. Joliot-Curie, 50-383 Wroctaw, Poland. E-mail: anna.trzeciak@chem.uni.wroc.pl

${ }^{b}$ Departamento de Química Inorgánica, Universidad de Granada, Av. Fuentenueva S/N, 18071 Granada, Spain.E-mail: jarn@ugr.es

$\dagger$ Electronic supplementary information (ESI) available: Experimental details, optimization of the reaction conditions, FT-IR spectra, XPS spectra, TGA curve, TEM image of Pd@[Ni( $\left.\left.\mathrm{H}_{2} \mathrm{BDP}_{-} \mathrm{SO}_{3}\right)_{2}\right]$ after 4 uses. See DOI: 10.1039/c6dt02242a
}

water-mediated coupling of aryl chlorides at $80{ }^{\circ} \mathrm{C}$ with a TBAB additive. $^{25}$ Palladium supported on amino-functionalized MIL-53(Al) $\mathrm{NH}_{2}$ catalyzed the Suzuki-Miyaura coupling with high activity and recyclability. ${ }^{26}$ The effect of palladium loading on the catalytic performance was studied for Pd NPs immobilized on MIL-101(Cr) $\mathrm{NH}_{2}$ and the best activity and recyclability were obtained for 8 wt $\%$ of Pd. ${ }^{27}$ Further studies with this catalyst indicated that the type of the base used in the catalytic reaction has a decisive influence on the stability of the MOF structure. ${ }^{28}$ Noteworthily, the MOF catalyst was degraded by the presence of carbonates, while it remained crystalline with fluorides. ${ }^{28}$ Decomposition of Pd-MIL-101(Cr) and leaching of the active phase were observed. ${ }^{29}$ A similar catalyst, Pd-MIL-101, containing well dispersed Pd NPs obtained by a "double solvent" method acted as the heterogeneous and recyclable catalyst of bromo- and iodobenzene coupling. ${ }^{30}$

Pd- $\mathrm{NH}_{2}$-MIL-125 catalyzed the Suzuki-Miyaura coupling of aryl chlorides at $100{ }^{\circ} \mathrm{C}$ in methanol with a yield of $c a .80 \% .{ }^{31}$ It was also successfully recycled and used in four subsequent runs. The catalyst Pd-UiO-66, obtained by the microwaveassisted method, exhibited high catalytic activity in the Suzuki-Miyaura coupling of aryl bromides and chlorides at $30{ }^{\circ} \mathrm{C} .{ }^{32} \mathrm{Pd}$ NPs dispersed on the surface of DUT-67 micro-crystals were used for coupling of iodobenzene at $70^{\circ} \mathrm{C}$ in waterethanol. ${ }^{33}$ Interestingly, the $\operatorname{Pd}(\mathrm{II})$ complex with a 2,2,-bypyridine-5,5,-dicarboxylate linker incorporated into the MOF (UiO-67) showed a remarkably higher activity than the homogeneous Pd counterparts. ${ }^{34}$

Noteworthily, while the Pd-MOF catalysts found application in the Suzuki-Miyaura coupling, this work represents the first example of their use under a $\mathrm{CO}$ atmosphere. To the best of our knowledge, the only example until now was reported for the Sonogashira carbonylative coupling with a $\mathrm{Pd}(\mathrm{II})-\mathrm{Zr}-\mathrm{MOF}-$ BIPY system. ${ }^{37}$

Most of the studies on the Pd-MOF systems in the SuzukiMiyaura reaction are based on carboxylate MOFs of the MIL/ 


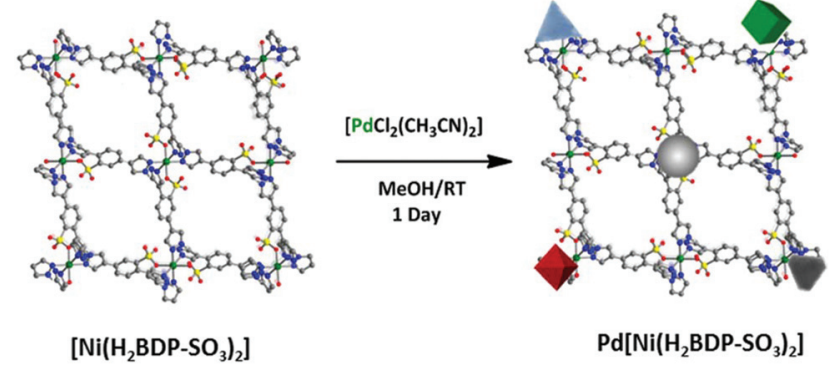

Scheme 1 Green preparation of $\mathrm{Pda}\left[\mathrm{Ni}\left(\mathrm{H}_{2} \mathrm{BDP}-\mathrm{SO}_{3}\right)_{2}\right]$ catalyst.

UiO families. In this regard, testing of other MOF materials of high chemical stability as supports for palladium could be beneficial. To this aim, MOFs containing strong donor azolate ligands like imidazolates or pyrazolates could be considered. ${ }^{38,39}$ Following this idea, we decided to choose pyrazolato based MOF containing sulfonate functionalities, $\left[\mathrm{Ni}\left(\mathrm{H}_{2} \mathrm{BDP}_{-} \mathrm{SO}_{3}\right)_{2}\right]$, for palladium immobilization. ${ }^{40}$ We expected that the system, built from the assembly of $\mathrm{Ni}$ (II) cations and 2,5-di(1H-pyrazol-4-yl)benzenesulfonate linkers might be a suitable MOF support for $\mathrm{Pd}^{2+}$ and Pd NPs since both palladium forms are present in the Suzuki-Miyaura catalytic cycle (Scheme 1). ${ }^{4,6,7}$

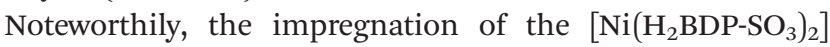
system with a methanolic solution of $\left[\mathrm{PdCI}_{2}\left(\mathrm{CH}_{3} \mathrm{CN}\right)_{2}\right]$ at room temperature gave rise to the straightforward formation of $\mathrm{Pd} @\left[\mathrm{Ni}\left(\mathrm{H}_{2} \mathrm{BDP} \mathrm{SO}_{3}\right)_{2}\right]$ containing both $\mathrm{Pd}^{2+}$ ions and $\mathrm{Pd} \mathrm{NPs}$ embedded in the MOF material. The uploaded amount of Pd, as determined by induced coupling plasma (ICP) analysis, is up to $5.6 \mathrm{wt} \%$. TEM images indicated that the Pd NPs are homogeneously distributed on the MOF microparticles (Fig. 1) (for details see the ESI $\dagger$ ). Remarkably, $\mathrm{MeOH}$ acted as both a solvent and a reductant. ${ }^{41}$ Indeed, we have observed a quick change of the colour of the $\left[\mathrm{PdCI}_{2}\left(\mathrm{CH}_{3} \mathrm{CN}\right)_{2}\right]$ solution from yellow to dark brown, while the MOF micropowder changed the colour from yellow to dark red, indicating that the palladium precursor was reduced to Pd NPs. The as-prepared Pd NPs were characterized by transmission electron microscopy (TEM) (see Fig. 1C and D) and elemental mapping images (Fig. 1E). The corresponding electron diffraction pattern (SAED) for the selected area is shown in Fig. 1B demonstrating that Pd NPs are crystalline. In the SAED pattern we observe the diffraction rings matched with (111), (200), (220), and (311) crystallographic planes of Pd nanocrystals, respectively. The TEM images also established that the palladium nanocrystals are in the 4-8 $\mathrm{nm}$ size distribution (Fig. 1A). It should also be noted that Pd NPs exhibit very-well defined geometrical shapes even though the synthesis conditions were very mild. This is unusual since the production of Pd NPs typically involves the addition of a reducing agent (i.e. $\mathrm{N}_{2} \mathrm{H}_{4}, \mathrm{NaBH}_{4}, \mathrm{H}_{2}$ ) leading to less defined shapes in most cases. ${ }^{42,43}$ In this regard, the use of methanol as a reducing agent, under the reported mild conditions, seems to be advantageous since it leads to a higher control over the shape and size of palladium nanocrystals com- pared to traditional reducing agents (Fig. 1D). Moreover, analysis of X-ray photoelectron spectroscopy (XPS) spectra confirmed the presence of both $\operatorname{Pd}(0)(334.0,339.3 \mathrm{eV})$ and $\mathrm{Pd}^{2+}(336.9,342.6 \mathrm{eV})$ in a $15: 85$ ratio. On the other hand, XPS lines of $\mathrm{Pd}^{2+}$ are shifted towards lower binding energies, as compared to pristine $\left[\mathrm{PdCl}_{2}\left(\mathrm{CH}_{3} \mathrm{CN}\right)_{2}\right]$ indicating a change of the palladium environment. In fact, FT-IR analysis exhibited that the characteristic absorbance band for a $\mathrm{C} \equiv \mathrm{N}$ bond at $c a$. $2340 \mathrm{~cm}^{-1}$ was absent (Fig. $\mathrm{S} 4 \dagger$ ), suggesting that $\mathrm{CH}_{3} \mathrm{CN}$ is removed from the coordination sphere of palladium during immobilization. The FT-IR region $600-100 \mathrm{~cm}^{-1}$ was also studied. There is a strong absorption band centred at $352 \mathrm{~cm}^{-1}$ which can unequivocally be assigned to $\nu(\mathrm{Pd}-\mathrm{Cl}) .{ }^{44}$ Additionally, EDX analysis shows a ca. 1:1 atomic ratio of $\mathrm{Pd}: \mathrm{Cl}$. These results suggest that $\mathrm{PdCl}^{+}$cations might be anchored to the outer surface of the Pd NPs and further stabilized in the $\left[\mathrm{Ni}\left(\mathrm{H}_{2} \mathrm{BDP}-\mathrm{SO}_{3}\right)_{2}\right]$ structure by interactions with sulfonate oxygen atoms of the organic linkers. Indeed, two additional bands centred at 420 and $455 \mathrm{~cm}^{-1}$ might be assigned to $\nu(\mathrm{Pd}-\mathrm{O})$, supporting the plausible interaction of the core shell NPs with the sulfonate groups of the organic spacers. Alternatively, additional stabilizing interactions between $\mathrm{Pd}-\mathrm{Cl}$ cations and $\mathrm{NH}$ groups of pyrazole could also be considered.

The low-angle XPRD pattern of the as-prepared $\left[\mathrm{Ni}\left(\mathrm{H}_{2} \mathrm{BDP}^{-\mathrm{SO}_{3}}\right)_{2}\right]$ (Fig. $\left.2 \mathrm{~A}\right)$ is in agreement with the simulated pattern reported by Colombo et al. ${ }^{40}$ In addition, the structure

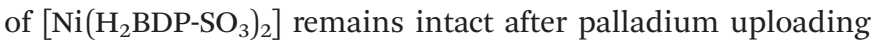
and no changes in the XPRD patterns were detected, which supports that $\left[\mathrm{Ni}\left(\mathrm{H}_{2} \mathrm{BDP}^{-\mathrm{SO}_{3}}\right)_{2}\right]$ was chemically stable during the palladium reduction process and ulterior catalytic reaction. We have also evaluated the effect of palladium incorporation into the $\left[\mathrm{Ni}\left(\mathrm{H}_{2} \mathrm{BDP}^{-\mathrm{SO}_{3}}\right)_{2}\right]$ system by means of $\mathrm{N}_{2}$ adsorption isotherms at $77 \mathrm{~K}$ (see Fig. $2 \mathrm{~B}$ and Table 1). Noteworthily, the porous structure in $\mathrm{Pd} @\left[\mathrm{Ni}\left(\mathrm{H}_{2} \mathrm{BDP}_{-} \mathrm{SO}_{3}\right)_{2}\right]$ is still highly accessible, although a diminution of approx. $45 \%$ in the specific surface area (SA) and pore volume is noticed. On the other hand, the TGA analysis reveals that the $\left[\mathrm{Ni}\left(\mathrm{H}_{2} \mathrm{BDP}_{-} \mathrm{SO}_{3}\right)_{2}\right]$ material possesses a notable thermal stability of up to $350{ }^{\circ} \mathrm{C}$ (Fig. S1 $\dagger$ ).

Once the physicochemical features of the $\mathrm{Pd} @\left[\mathrm{Ni}\left(\mathrm{H}_{2} \mathrm{BDP}-\mathrm{SO}_{3}\right)_{2}\right]$ composites were established we proceed to evaluate their plausible catalytic properties.

The $\mathrm{C}-\mathrm{C}$ coupling reactions between aryl halides $(-\mathrm{Br},-\mathrm{Cl})$ and phenylboronic acid were selected as model reactions for testing the catalytic activity of $\mathrm{Pd} @\left[\mathrm{Ni}\left(\mathrm{H}_{2} \mathrm{BDP}_{-} \mathrm{SO}_{3}\right)_{2}\right]$. With this aim, the reaction parameters were optimized using 4-bromoanisole as a screening substrate, and the results are summarized in Tables 2 and S1 (see the ESI $\dagger$ ).

The reaction did not proceed either in the absence of a catalyst (Table $\mathrm{S} 1$, entry $1 \dagger$ ) or in the presence of pristine $\left[\mathrm{Ni}\left(\mathrm{H}_{2} \mathrm{BDP}_{-} \mathrm{SO}_{3}\right)_{2}\right]$ (Table $\mathrm{S} 1$, entry $\left.2 \dagger\right)$, which confirms the catalytic activity of Pd@[Ni( $\left.\left(\mathrm{H}_{2} \mathrm{BDP}-\mathrm{SO}_{3}\right)_{2}\right]$. Indeed, $\left.\mathrm{Pd@[Ni(}\left(\mathrm{H}_{2} \mathrm{BDP}^{-\mathrm{SO}_{3}}\right)_{2}\right]$ was active, in 1:1 2-propanol and water solvent mixtures at $25{ }^{\circ} \mathrm{C}$ forming up to $91 \%$ of the coupling product. Under these conditions $\left(25^{\circ} \mathrm{C}\right)$ reactions of different aryl halides with phenylboronic acid showed conversions from 


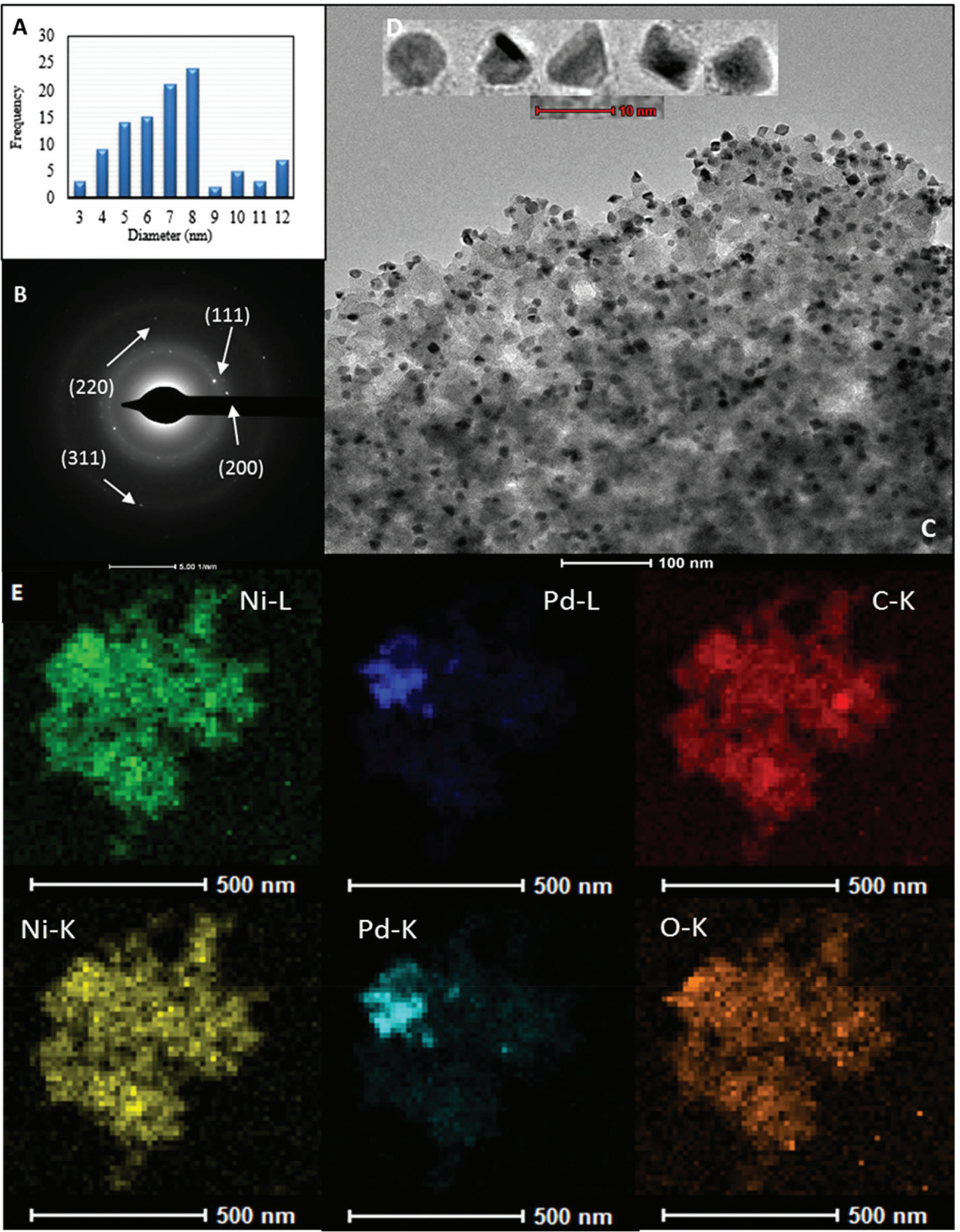

Fig. 1 (A) Histogram of Pd particle size, (B) SAED pattern of Pd nanocrystals, (C, D) TEM images of Pd NPs with different shapes found in $\mathrm{Pd} @\left[\mathrm{Ni}\left(\mathrm{H}_{2} \mathrm{BDP}-\mathrm{SO}_{3}\right)_{2}\right]$ nanocrystals, (E) EDX elemental mappings of $\mathrm{Pd} \mathrm{C}\left[\mathrm{Ni}\left(\mathrm{H}_{2} \mathrm{BDP}-\mathrm{SO}_{3}\right)_{2}\right]$.

$30 \%$ for 2 -chlorotoluene to $91 \%$ for 4-bromoanisole and 4-bromotoluene. The highest conversions, up to $97-99 \%$, were obtained for 2-bromotoluene, 4-bromotoluene and 4-bromoanisole at $60^{\circ} \mathrm{C}$ after a $4 \mathrm{~h}$ reaction (Table 2). Kinetic profiles of Suzuki-Miyaura reactions of 4-bromoanisole, illustrating a positive effect of a higher temperature on the reaction course, are shown in Fig. 3. By contrast, in the reaction of 2-chlorotoluene at $100{ }^{\circ} \mathrm{C}$ only $24 \%$ of the corresponding coupling 
A

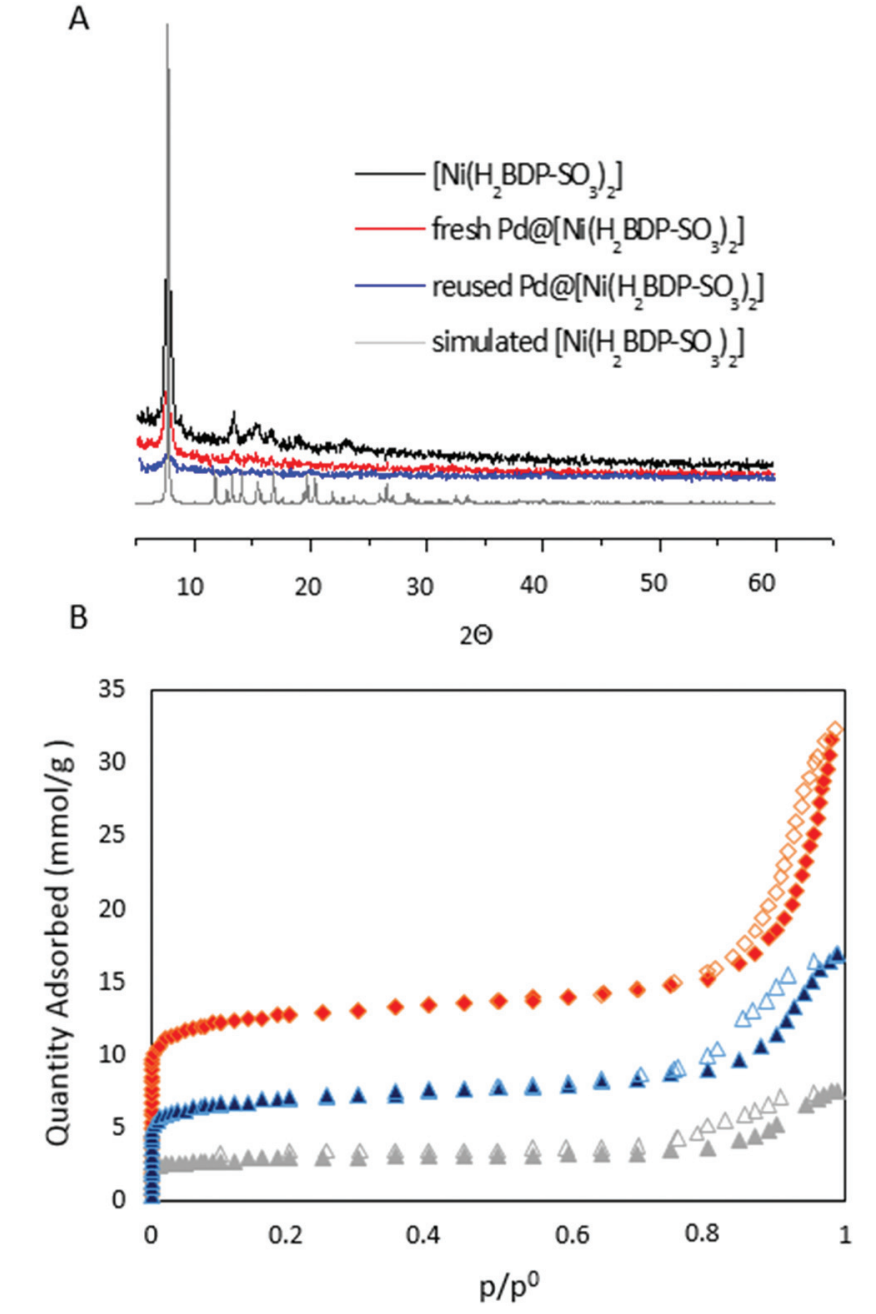

.

Fig. 2 (A) XPRD patterns of $\left[\mathrm{Ni}\left(\mathrm{H}_{2} \mathrm{BDP}-\mathrm{SO}_{3}\right)_{2}\right]$ as synthesized (black), $\mathrm{Pd}\left(\mathrm{Ni}\left(\mathrm{H}_{2} \mathrm{BDP}-\mathrm{SO}_{3}\right)_{2}\right]$ (red), 4-use catalytic cycle (blue), simulated (grey) $i^{40}$ (B) $\mathrm{N}_{2}$ adsorption isotherms measured at $77 \mathrm{~K}$ for $\left[\mathrm{Ni}\left(\mathrm{H}_{2} \mathrm{BDP}-\mathrm{SO}_{3}\right)_{2}\right]$ (red), $\mathrm{Pd} \mathrm{a}\left[\mathrm{Ni}\left(\mathrm{H}_{2} \mathrm{BDP}-\mathrm{SO}_{3}\right)_{2}\right]$ (blue) and reused $\mathrm{Pd} a\left[\mathrm{Ni}\left(\mathrm{H}_{2} \mathrm{BDP}-\mathrm{SO}_{3}\right)_{2}\right]$ (grey). Filled and empty symbols represent adsorption and desorption, respectively.

Table $1 \mathrm{~N}_{2}$ sorption isotherm data of $\left[\mathrm{Ni}\left(\mathrm{H}_{2} \mathrm{BDP}-\mathrm{SO}_{3}\right)_{2}\right]$ and $\mathrm{Pd} \mathrm{C}\left[\mathrm{Ni}\left(\mathrm{H}_{2} \mathrm{BDP}-\mathrm{SO}_{3}\right)_{2}\right]$

\begin{tabular}{lll}
\hline Sample $^{a}$ & $S_{\text {BET }}\left(\mathrm{m}^{2} \mathrm{~g}^{-1}\right)$ & $V_{\text {pore }}\left(\mathrm{cm}^{3} \mathrm{~g}^{-1}\right)$ \\
\hline$\left[\mathrm{Ni}\left(\mathrm{H}_{2} \mathrm{BDP}-\mathrm{SO}_{3}\right)_{2}\right]$ & $1082(2)$ & 1.11 \\
$\mathrm{Pd}\left[\mathrm{Ni}\left(\mathrm{H}_{2} \mathrm{BDP}_{-} \mathrm{SO}_{3}\right)_{2}\right]$ & $583(2)$ & 0.58 \\
$\mathrm{Pd} @\left[\mathrm{Ni}\left(\mathrm{H}_{2} \mathrm{BDP}_{-} \mathrm{SO}_{3}\right)_{2}\right]^{b}$ & $246(1)$ & 0.26
\end{tabular}

${ }^{a}$ Desolvated under reduced pressure at $180{ }^{\circ} \mathrm{C}$ for $12 \mathrm{~h} .{ }^{b}$ Reused $\mathrm{Pd} @\left[\mathrm{Ni}\left(\mathrm{H}_{2} \mathrm{BDP}-\mathrm{SO}_{3}\right)_{2}\right]$.

product was formed as a result of higher strength of the $\mathrm{C}-\mathrm{Cl}$ bond compared to $\mathrm{C}-\mathrm{Br}$ (Table 2). The recyclability of the $\mathrm{Pd} @\left[\mathrm{Ni}\left(\mathrm{H}_{2} \mathrm{BDP}-\mathrm{SO}_{3}\right)_{2}\right]$ catalyst was tested over the Suzuki-Miyaura reaction (Fig. 4). After each run, the solid catalyst was easily collected by centrifugation, washed with $\mathrm{MeOH}$, and used for a further run up to four consecutive runs under the same conditions.
Table 2 Pd@ $\left[\mathrm{Ni}\left(\mathrm{H}_{2} \mathrm{BDP}-\mathrm{SO}_{3}\right)_{2}\right]$ catalyzed Suzuki-Miyaura coupling showing the effect of substituents in aryl halides ${ }^{a}$

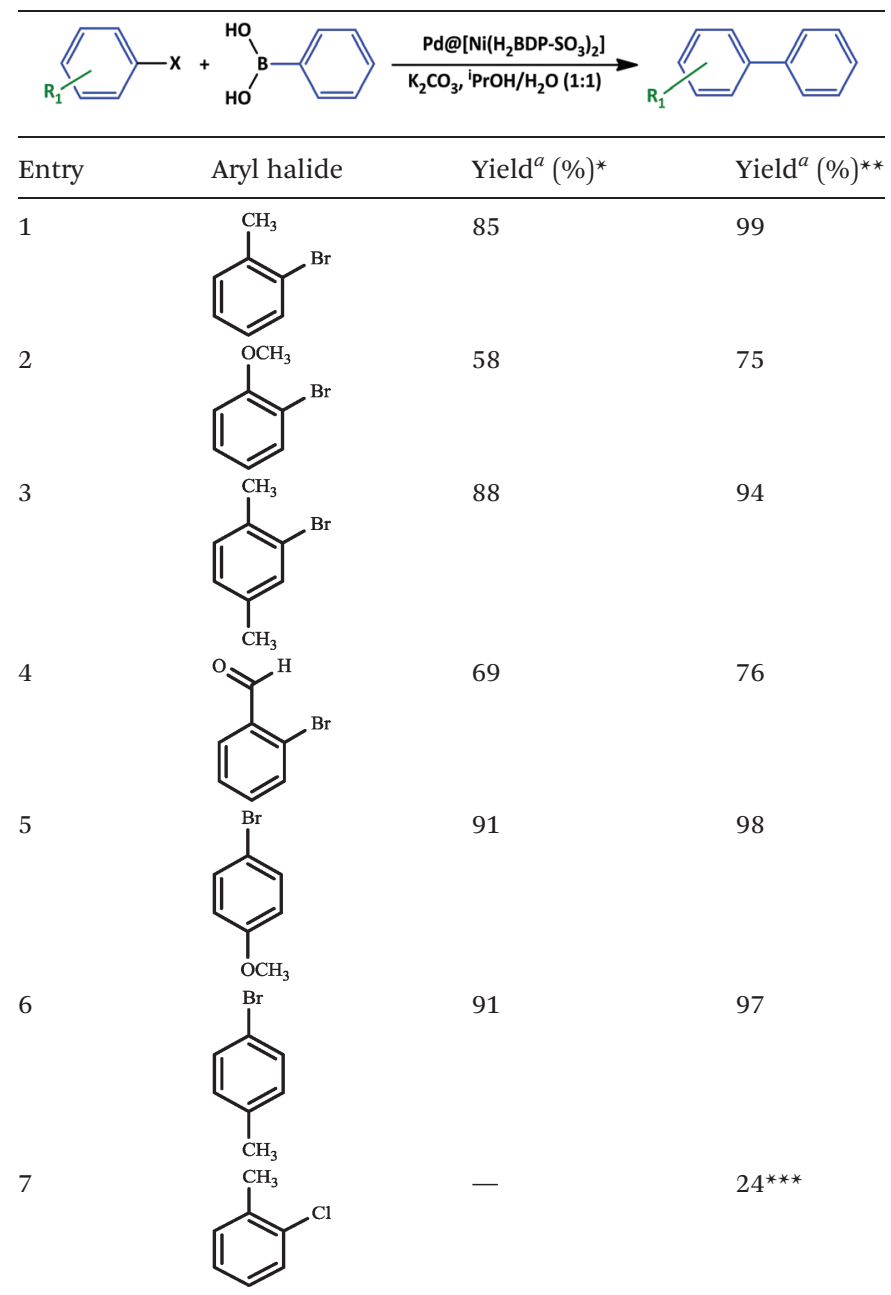

${ }^{a}$ Reaction conditions: aryl halide $(1 \mathrm{mmol})$, phenylboronic acid (1.5 mmol), $\mathrm{K}_{2} \mathrm{CO}_{3}(1.5 \mathrm{mmol})$, ${ }^{\mathrm{i}} \mathrm{PrOH}(2.5 \mathrm{~mL}), \mathrm{H}_{2} \mathrm{O}(2.5 \mathrm{~mL})$, $\mathrm{Pd} @\left[\mathrm{Ni}\left(\mathrm{H}_{2} \mathrm{BDP}-\mathrm{SO}_{3}\right)_{2}\right](0.5 \mathrm{~mol} \%$ of Pd $),{ }^{*} 8 \mathrm{~h}$ at $25{ }^{\circ} \mathrm{C},{ }^{* *} 4 \mathrm{~h}$ at $60{ }^{\circ} \mathrm{C}$, $* * * 20 \mathrm{~h}$ at $100^{\circ} \mathrm{C}$

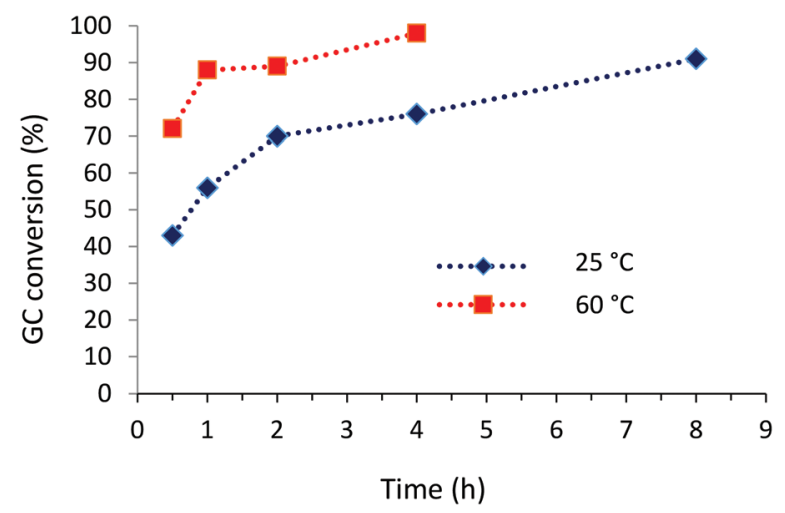

Fig. 3 Time conversion plot for the Suzuki-Miyaura coupling of 4-bromoanisole with phenylboronic acid. 


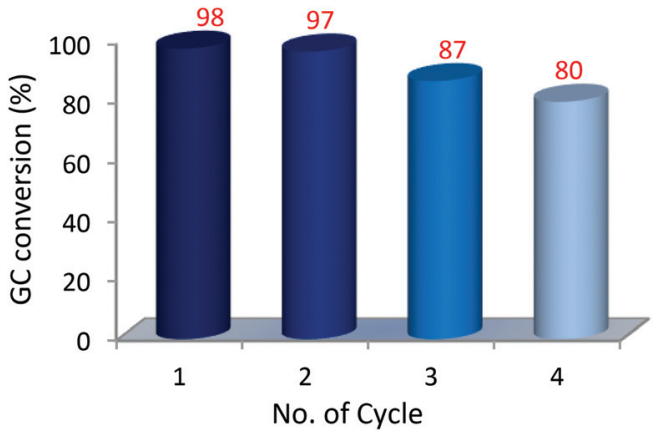

Fig. 4 Recycling catalytic test of $\mathrm{Pd} @\left[\mathrm{Ni}\left(\mathrm{H}_{2} \mathrm{BDP}-\mathrm{SO}_{3}\right)_{2}\right]$. Reaction conditions: 4-bromoanisole $(1 \mathrm{mmol})$, phenylboronic acid $(1.2 \mathrm{mmol})$, $\mathrm{K}_{2} \mathrm{CO}_{3}(1.5 \mathrm{mmol}), \mathrm{PdQ}\left[\mathrm{Ni}\left(\mathrm{H}_{2} \mathrm{BDP}-\mathrm{SO}_{3}\right)_{2}\right] .(0.5 \mathrm{~mol} \%$ of $\mathrm{Pd}) \mathrm{H}_{2} \mathrm{O} / \mathrm{PrOH}$ $(5 \mathrm{~mL}), 60^{\circ} \mathrm{C}, 4 \mathrm{~h}$.

The results show a relatively small conversion decrease, from 98 to $80 \%$, highlighting the good stability of the $\mathrm{Pd} @\left[\mathrm{Ni}\left(\mathrm{H}_{2} \mathrm{BDP}-\mathrm{SO}_{3}\right)_{2}\right]$ catalyst. After the 4 th use, the catalyst was examined by XPRD (Fig. 2A) and TEM (Fig. S3†) and showed a certain degree of MOF crystallinity loss. Noteworthily, the amount of $\operatorname{Pd}(0)$ increased from the original 15\% to $39 \%$ similarly to other heterogenized palladium systems in SuzukiMiyaura reactions ${ }^{45-47}$ (Fig. S2 $\dagger$ ). To estimate the role of soluble palladium forms leached from the solid support, in the catalytic process, the activity of the liquid phase was investigated. However, the filtrate obtained after separation of the

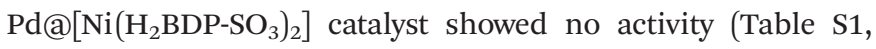
entry $7 \dagger$ ). According to ICP analysis, the palladium content in the liquid phase was $0.035 \mathrm{ppm}$ evidencing insignificant palladium leaching. Consequently, the heterogeneous reaction pathway can be proposed as the main one, with catalytic activity taking place on the Pd NP surface.

Furthermore, TEM images of the recovered catalyst indicate that the Pd NPs are homogeneously dispersed even after the catalytic reactions (Fig. 5A and B).

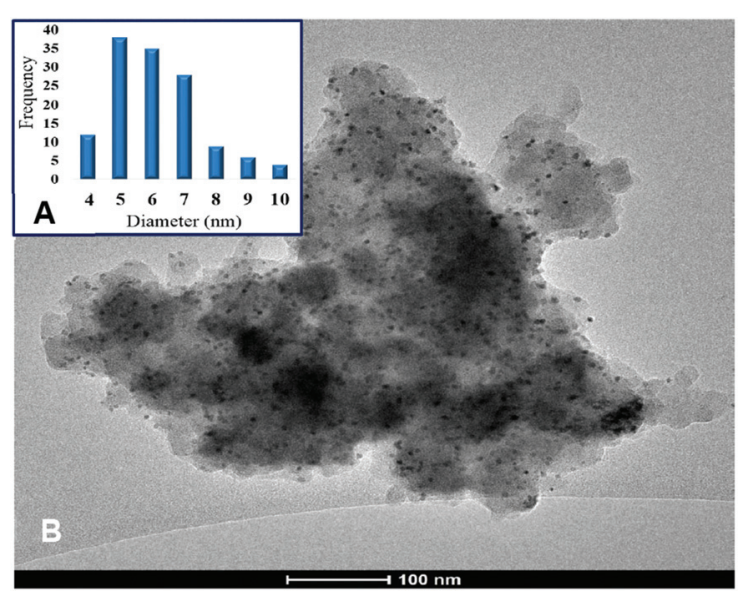

9

10

8

6 (5 bar), ${ }^{* *} \mathrm{CO}(10 \mathrm{bar}) .{ }^{b} 0.5 \mathrm{~mol} \%$ of Pd at $105^{\circ} \mathrm{C}$.
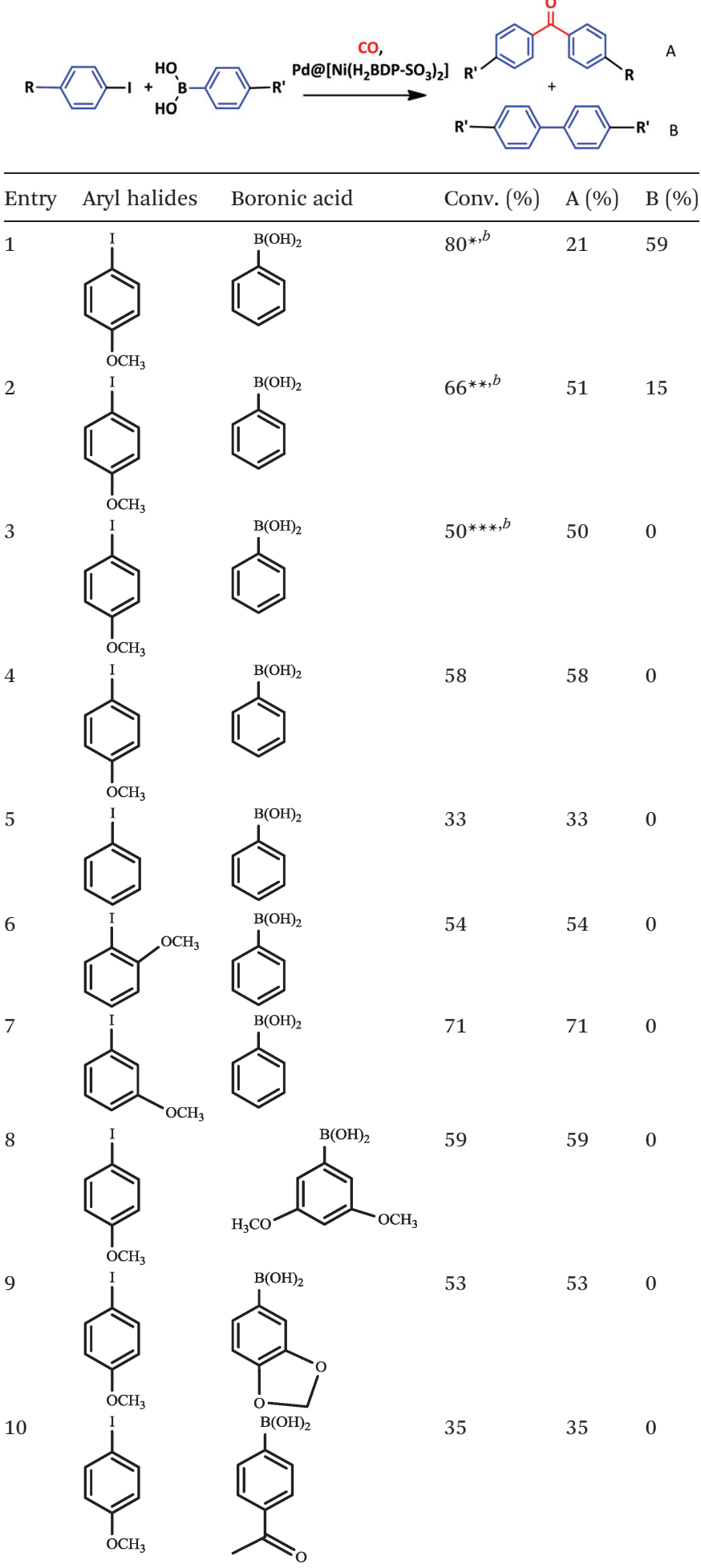

${ }^{a}$ Reaction conditions: aryl halide $(1 \mathrm{mmol})$, phenylboronic acid

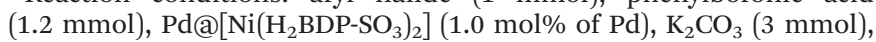
solvent (anisole) $5 \mathrm{~mL}$, CO (10 bar) at $105{ }^{\circ} \mathrm{C} .{ }^{*} \mathrm{CO}$ balloon, ${ }^{* *} \mathrm{CO}$

Fig. 5 (A) Histogram of Pd NPs; (B) TEM images of Pd@ $\left[\mathrm{Ni}\left(\mathrm{H}_{2} \mathrm{BDP}-\mathrm{SO}_{3}\right)_{2}\right]$ catalyst after reaction. 
Moreover, agglomeration of Pd NPs was not appreciable but some decrease of an average size was noted. The morphology was also changed and Pd NPs became more round. These observations support the suggestion that Pd NPs do actively participate in the catalytic reaction taking place on their surface. The Pd amount found in the reused $\mathrm{Pd} @\left[\mathrm{Ni}\left(\mathrm{H}_{2} \mathrm{BDP}-\mathrm{SO}_{3}\right)_{2}\right]$, as determined by ICP analysis, was $5.3 \mathrm{wt} \%$. The specific area determined by $\mathrm{N}_{2}$ adsorption decreased to $246 \mathrm{~m}^{2} \mathrm{~g}^{-1}$, probably as a result of incorporation of organic products into pores (Table 1). As the leaching of palladium was not significant, it can be assumed that the decrease of the catalytic activity during recycling is caused by lower availability of active palladium centres blocked by organic products.

Once we proved that the $\mathrm{Pd} @\left[\mathrm{Ni}\left(\mathrm{H}_{2} \mathrm{BDP}-\mathrm{SO}_{3}\right)_{2}\right]$ system was catalytically active in the Suzuki-Miyaura coupling, we decided to test it in a more demanding reaction, like carbonylative Suzuki-Miyaura coupling. It was interesting to check whether the catalytic activity can be switched from standard coupling to the carbonylative coupling by a simple change in the reaction conditions. The carbonylative coupling of iodoanisole with phenylboronic acid was selected as the model reaction, and the results are summarized in Tables 3 and S2 (see the $\mathrm{ESI} \dagger$ ). Anisole, toluene and DMF were chosen as solvents, while $\mathrm{K}_{2} \mathrm{CO}_{3}, \mathrm{KHCO}_{3}$ and $\mathrm{KOH}$ were selected as bases. At 1 bar of CO only $21 \%$ of diarylketone was formed, however, its yield increased to $51 \%$ after pressure was increased to 5 bar. At 10 bar of CO diarylketone was obtained as the only product. Consequently, this pressure was used in further experiments performed in anisole as a solvent with $1 \mathrm{~mol} \%$ of $\mathrm{Pd} @\left[\mathrm{Ni}\left(\mathrm{H}_{2} \mathrm{BDP}-\mathrm{SO}_{3}\right)_{2}\right]$. Reactions of different aryliodides with phenylboronic acid show conversions from 33\% to $71 \%$ (Table 3). The highest conversion, up to $71 \%$, was obtained for 3-iodoanisole. Typically, a correlation between the conversion and position of the substituent in the aryl ring is observed.

The much higher reactivity of 3-iodoanisole, as compared to 4-iodoanisole and 2-iodoanisole, may be attributed to the reduced pore availability of $\mathrm{Pd} @\left[\mathrm{Ni}\left(\mathrm{H}_{2} \mathrm{BDP}-\mathrm{SO}_{3}\right)_{2}\right]$ for a 3-iodoanisole molecule facilitating the reaction on the surface of $\mathrm{Pd} @\left[\mathrm{Ni}\left(\mathrm{H}_{2} \mathrm{BDP}_{-} \mathrm{SO}_{3}\right)_{2}\right]$. Reactions with substituted boronic acids showed conversions ranging from 59\% for 3,5-dimethoxyboronic acid to $35 \%$ for 4 -acetylphenylboronic acid. Interestingly the best yield was observed for bulky 3,5-dimethoxyboronic acid. In

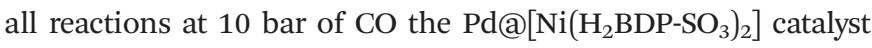
gave exceptionally $100 \%$ selectivity.

\section{Conclusions}

A new green synthetic method leading to $\mathrm{Pd} @\left[\mathrm{Ni}\left(\mathrm{H}_{2} \mathrm{BDP}-\mathrm{SO}_{3}\right)_{2}\right]$ containing $\mathrm{Pd}^{2+}$ and Pd NPs in a Ni(II) pyrazolate MOF has been presented. Noteworthily, the obtained crystalline Pd NPs supported on the $\left[\mathrm{Ni}\left(\mathrm{H}_{2} \mathrm{BDP}-\mathrm{SO}_{3}\right)_{2}\right]$ MOF material can be regarded as a highly active heterogeneous catalyst for the Suzuki-Miyaura coupling in an environmentally friendly mixture of solvents (2-propanol/water). The catalyst can be recovered and reused for at least four runs without a significant loss in its activity.
At $25{ }^{\circ} \mathrm{C}$ our catalyst converted $91 \%$ of 4 -bromotoluene and 4-bromoanisole to the coupling products. As far as we know, only for a Zn-free MOF-5-NPC-Pd catalyst very good results were obtained at $25{ }^{\circ} \mathrm{C} .{ }^{36}$ In other MOF systems a higher temperature (40-200 ${ }^{\circ} \mathrm{C}$ ) was applied. The catalytic activity reported by us at $60{ }^{\circ} \mathrm{C}$ with $0.5 \mathrm{~mol} \%$ of $\mathrm{Pd}$ is similar to that found for Pd/MIL-53-NH ${ }_{2}{ }^{30}$ and Pd-MCM-41. ${ }^{51}$ On the other hand, a higher activity in the Suzuki-Miyaura reaction was shown by $\mathrm{Pd} / \mathrm{MOF}$ which produced $92 \%$ of the coupling product at $40{ }^{\circ} \mathrm{C}$ in $0.5 \mathrm{~h}^{35}$ Under the same conditions this catalyst converted other bromoarenes to appropriate products in $87-95 \% .^{35}$

The activity of the $\mathrm{Pd} @\left[\mathrm{Ni}\left(\mathrm{H}_{2} \mathrm{BDP}-\mathrm{SO}_{3}\right)_{2}\right]$ catalyst can be easily switched to carbonylative coupling by introduction of $\mathrm{CO}$ and the excellent selectivity to diarylketone was noted at 10 bar of CO. According to the best of our knowledge we have reported for the first time the results of carbonylative coupling with a MOF supported Pd catalyst. At 1 bar of CO our catalyst produced $21 \%$ of ketone, showing lower activity than Pd nanoparticles supported on dopamine-functionalized magnetite. ${ }^{49}$ Palladium nanoparticles immobilized onto SILLP formed diarylketones with the yield of $60-87 \%$ in $12 \mathrm{~h}$ at 30 atm of CO at $120{ }^{\circ} \mathrm{C} .{ }^{50}$ These conditions are significantly harsher than used by us. The Pd catalyst supported on amino-modified silica microspheres used at $5 \mathrm{~atm}$ of CO in an amount of $0.05 \mathrm{~mol} \%$ gave better results, up to $90 \%$ conversion, in 5 h. ${ }^{48}$

Further work on exploring new catalytic reactions with such a Pd@MOF system is currently underway.

\section{Acknowledgements}

We are grateful for financial support from National Science Centre (NCN, Poland) with grant 2014/15/B/ST5/02101 (A. W. A., W. Z., A. M. T.), Spanish MINECO (CTQ2014-53486-R) and EU FEDER Funding (JARN).

\section{Notes and references}

1 B. C. Gates, Chem. Rev., 1995, 95, 511.

2 D. Astruc, F. Lu and J. R. Aranzaes, Angew. Chem., Int. Ed., 2005, 44, 7852 .

3 A. Molnar, in Palladium catalyzed coupling reactions, ed. A. Molnar, Wiley-VCH Verlag GmbH \& Co. KGaA, Weinheim, Germany, 2013.

4 N. T. S. Phan, M. van der Sluys and C. W. Jones, Adv. Synth. Catal., 2006, 348, 609.

5 L. Yin and J. Liebscher, Chem. Rev., 2007, 107, 133.

6 A. M. Trzeciak and J. J. Ziółkowski, Coord. Chem. Rev., 2005, 249, 2308.

7 A. M. Trzeciak and J. J. Ziółkowski, Coord. Chem. Rev., 2007, 251, 1281.

8 N. Miyaura and A. Suzuki, Chem. Rev., 1995, 95, 2457.

9 A. Suzuki, J. Organomet. Chem., 1999, 576, 147.

10 N. Miyaura, Top. Curr. Chem., 2002, 219, 11. 
11 C. Torborg and M. Beller, Adv. Synth. Catal., 2009, 351, 3027.

12 J. Magano and J. R. Dunetz, Chem. Rev., 2011, 111, 2177.

13 X.-F. Wu, H. Neumann and M. Beller, Chem. Soc. Rev., 2011, 40, 4986.

14 S. T. Gadge and B. M. Bhanage, RSC Adv., 2014, 4, 10367.

15 R. Skoda-Földes and L. Kollár, Curr. Org. Chem., 2002, 6, 1097.

16 J. Gascon, A. Corma, F. Kapteijn and F. X. Llabres i Xamena, ACS Catal., 2014, 4, 361.

17 Y. Wu, D. Wang and Y. Li, Chem. Soc. Rev., 2014, 43, 2112.

18 J. Liu, L. Chen, H. Cui, J. Zhang, L. Zhang and Ch. Su, Chem. Soc. Rev., 2014, 43, 6011.

19 Y. Yoon, R. Srirambalaji and K. Kim, Chem. Rev., 2011, 112, 1196.

20 A. H. Chughtai, N. Ahmad, H. A. Younus, A. Laypkov and F. Verpoort, Chem. Soc. Rev., 2015, 44, 6804.

21 Y. Zhang, Y. Zou, Y. Zhao and C.-J. Liu, Catal. Today, 2016, 263, 61.

22 Q.-L. Zhu and Q. Xu, Chem. Soc. Rev., 2014, 43, 5468.

23 J. A. R. Navarro, E. Barea, J. M. Salas, N. Masciocchi, S. Galli, A. Sironi, C. O. Ania and J. B. Parra, Inorg. Chem., 2006, 45, 2397.

24 F. X. Llabrés i Xamena, A. Abad, A. Corma and H. Garcia, J. Catal., 2007, 250, 294.

25 B. Yuan, Y. Pan, Y. Li, B. Yin and H. Jiang, Angew. Chem., Int. Ed., 2010, 49, 4054.

26 Y. Huang, Z. Zheng, T. Liu, J. Lü, Z. Lin, H. Li and R. Cao, Catal. Commun., 2011, 14, 27.

27 V. Pascanu, Q. Yao, A. B. Gomez, M. Gustafsson, Y. Yun, W. Wan, L. Samain, X. Zou and B. Martin-Matute, Chem. Eur. J., 2013, 19, 17483.

28 F. Carson, V. Pascanu, A. B. Gómez, Y. Zhang, A. E. PlateroPrats, X. Zou and B. Martin-Matute, Chem. - Eur. J., 2015, 21, 10896.

29 J. Juan-Alcañiz, J. Ferrando-Soria, I. Luz, P. Serra-Crespo, E. Skupien, V. P. Santos, E. Pardo, F. X. Llabrés i Xamena, F. Kapteijn and J. Gascon, J. Catal., 2013, 307, 295.

30 N. Shang, S. Gao, X. Zhou, Ch. Feng, Z. Wang and Ch. Wang, RSC Adv., 2014, 4, 54487.

31 P. Puthiaraj and W.-S. Ahn, Catal. Commun., 2015, 65, 91.

32 W. Dong, Ch. Feng, L. Zhang, N. Shang, S. Gao, Ch. Wang and Z. Wang, Catal. Lett., 2016, 146, 117.
33 G.-L. Zhuang, J.-Q. Bai, L. Tan, H.-L. Huang, Y.-F. Gao, X. Zhong, C.-L. Zhong and J.-G. Wang, RSC Adv., 2015, 5, 32714.

34 L. Chen, S. Rangan, J. Li, H. Jiang and Y. Li, Green Chem., 2014, 16, 3978.

35 L. Zhang, Z. Su, F. Jiang, Y. Zhou and W. Xu, Tetrahedron, 2013, 69, 9237.

36 W. Dong, L. Zhang, Ch. Wang, Ch. Feng, N. Shang, S. Gao and Ch. Wang, RSC Adv., 2016, 6, 37118.

37 C. Bai, S. Jian, X. Yao and Y. Li, Catal. Sci. Technol., 2014, 4, 3261.

38 V. Colombo, S. Galli, H. J. Choi, G. D. Han, A. Maspero, G. Palmisano, N. Masciocchi and J. R. Long, Chem. Sci., 2011, 2, 1311.

39 J. J. Low, A. I. Benin, P. Jakubczak, J. F. Abrahamian, S. A. Faheem and R. R. Willis, J. Am. Chem. Soc., 2009, 131, 15834.

40 V. Colombo, C. Montoro, A. Maspero, N. Masciocchi, S. Galli, E. Barea and J. A. R. Navarro, J. Am. Chem. Soc., 2012, 134, 12830.

41 M. Pourkhosravani, S. Dehghanpour and F. Farzaneh, Catal. Lett., 2016, 146, 499.

42 H. Li, Z. Zhu, F. Zhang, S. Xie, H. Li, P. Li and X. Zhou, ACS Catal., 2011, 1, 1604.

43 B. Gole, U. Sanyal, R. Banerjee and P. S. Mukherjee, Inorg. Chem., 2016, 55, 2345.

44 A. de Leon, M. Guerrero, J. Garcia-Antón, J. Ros, M. FontBardia and J. Pons, CrystEngComm, 2013, 15, 1762.

45 A. Gniewek, J. J. Ziółkowski, A. M. Trzeciak, M. Zawadzki, H. Grabowska and J. Wrzyszcz, J. Catal., 2008, 254, 121.

46 W. Zawartka, P. Pośpiech, M. Cypryk and A. M. Trzeciak, J. Mol. Catal. A: Chem., 2015, 407, 230.

47 E. Mieczyńska, T. Borkowski, M. Cypryk, P. Pośpiech and A. M. Trzeciak, Appl. Catal., A, 2014, 470, 24.

48 W. Zawartka, P. Pośpiech, M. Cypryk and A. M. Trzeciak, J. Mol. Catal. A: Chem., 2016, 417, 76.

49 Y. Long, K. Liang, J. Niu, X. Tong, B. Youan and J. Ma, New J. Chem., 2015, 39, 2988.

50 N. Jiao, Z. Li, Y. Wang, J. Liu and Ch. Xia, RSC Adv., 2015, 5, 26913.

51 S. Jana, S. Haldar and S. Koner, Tetrahedron Lett., 2009, 50, 4820 . 